"The South Asian Presence in Britain and its Transnational Connections" and Singh, H. and Vertovec, S. (eds)

Culture and Economy in the Indian Diaspora, London: Routledge, 2002

\title{
The South Asian Presence in Britain and its Transnational connections
}

\author{
Roger Ballard
}

\section{Introduction}

The rapid growth of Britain's South Asian population during the second half of the twentieth century, such that it included nearly two million people by the turn of the millennium, is best understood as the most recent manifestation of a dynamic series of inter-connections between the British Isles and the Indian subcontinent which were first began to emerge as Britain set about an Imperial presence in South Asia, and which are now developing yet further - albeit on rapidly changing terms - in a post-Imperial context. In that process of transformation 1947 was a turning point in three quite separate senses. In the first place it marked the point at which, as Pandit Nehru put it, India fulfilled its tryst with destiny, and thus awoke to life and freedom: the British Raj had come to an end. Secondly, and just as significantly, it did so not as a single unit, but as two separate states, which were before long to become three: India, Pakistan and Bangladesh - each of which have followed increasingly different socioeconomic trajectories as the years have passed. Thirdly, and just as importantly it marked the start of Britain's post-war economic boom, and with it the beginnings of a phenomenon which ultimately precipitated some equally significant transformations in the character of Anglo-Indian relationships: the large scale immigration of migrant workers of South Asian descent.

Not that labour immigration was in any sense a novel phenomenon, particularly in Britain's industrial cities. Every period of rapid industrial expansion during the nineteenth century precipitated acute shortages of unskilled manual labour, and the gaps were filled by recruiting additional hands from elsewhere, firstly from the countryside, then from Ireland, and subsequently from Eastern Europe. However as the post-war economic boom began to take off the ground, these traditional reservoirs could no longer provide the necessary manpower, with the result that employers had no alternative but to adopt a much more open-minded attitude to labour recruitment. This led to a profound transformation. Whilst people of colour who found their way to Britain - as seamen, for example - had hitherto found it virtually 
impossible to break into the local labour market, they suddenly found that foremen were willing to take them on, albeit to undertake tasks which no-one else was prepared to do. And although all this was initially regarded as a temporary measure - no less by migrant workers than by their employers - it set in train what eventually proved to be a process of reverse colonisation. Imperial transactions had manifestly ceased to be a one-way process.

However such massive role-reversals do not occur instantaneously. Hence whilst 1947 may indeed have been a crucial turning-point, the foundations on which the process of mass migration subsequently grew up had begun to be laid down many years earlier. Moreover the transformation is still under way. To be sure Britain's Indian Raj collapsed many years ago. Nevertheless the ideological assumptions which generated when it was still in place, such that British of thinking and acting were confidently assumed to be innately superior to all things Indian are still secretly shared by most members of Britain's indigenous majority. But although British South Asians therefore still have an uphill struggle on their hands, they are by no means pawns in the face of the resultant forces of racial and ethnic exclusionism. Far from it. Just as in the process of migration itself, both settlers and their offspring have been actively - and indeed very successfully - engaged in devising all manner of strategies with which to resist, and indeed to subvert, the worst aspects of the exclusionary pressures to which they found themselves exposed. In many respects reverse colonisation, mounted in this case 'from below', has been a key to their success. Besides providing a highly effective basis for the construction of networks of mutual support, the maintenance of swadeshi-inspired lifestyles and their associated conceptual structures has provided settlers - and even more so their British-born offspring - with a series of equally effective platforms from which to challenge the ideological assumptions of Britain's indigenous majority.

On the face of it these developments are a comprehensively British phenomenon. Not only have they been generated in the context of the local social order, but they are also precipitating some far-reaching changes in its character. Nevertheless members of each of Britain's many South Asian communities are also involved in an elaborate series of transnational linkages, most of which are grounded in ties of kinship, such that they also continue to participate in all sorts of significant ways in their communities of origin in the subcontinent. However the intensity of these linkages varies. For those who grew up in South Asia, such ties are normally still intense: many still dream of returning 'home' on a permanent basis, as they had almost all initially assumed to be the case. By contrast those 
born and raised overseas have - as we shall see - a much more complex relationship with their ancestral origins.

\section{The growth of the South Asian presence in Britain}

\subsection{Early history}

Although mass migration from South Asia was essentially a late twentieth century phenomenon, its foundations were laid down much earlier: indeed contacts with Britain had a history almost as long as the Imperial project itself. In her study of such contacts during the nineteenth and early twentieth centuries, Vizram (1986) identifies three major categories of sojourner. Firstly the personal servants of Imperial adventurers and administrators, who accompanied their masters (and mistresses) on their eventual return home; secondly seamen, all of whom worked in an equally menial capacity on British merchant ships, since they invariably served in the stokehold; and thirdly much more affluent travellers who came to Britain in search of a mixture of adventure, excitement and professional qualifications. Both Gandhi and Jinnah fell into the latter category. But until the beginning of the twentieth century the South Asian presence in Britain remained minute. At any given time it would have included no more than a few hundred Ayahs and Lascars, a rather smaller number of students seeking professional qualifications, whilst the number of Princes and other aristocrats - most of whom only made the briefest of visits - could probably have been counted on the fingers of one hand.

However the outbreak of the Great War in 1914 brought about some dramatic changes. Since so many male members of the indigenous working class had left for the trenches, acute shortages of industrial labour soon emerge. As a result ex-seamen who had hitherto scratched out a living as pedlars suddenly found that their physical appearance was no longer an obstacle to gaining waged employment. Secondly, and just as importantly, several British Indian regiments were sent over to France to reinforce the war effort. Since the use of Indian troops in European context was wholly unprecedented, exceptional, it was taken for granted they should promptly be shipped back to India once hostilities were over. Nevertheless a small number of sipahis bucked the trend. Taking advantage of their temporary presence in the Imperial heartlands, they took take a leaf out of the ex-lascars' book: having slipped quietly AWOL, they sought to take advantage of local opportunities. 
However the going turned out to be extremely tough, no less for the ex-seamen than the exsoldiers, since demobilised English soldiers, who were invariably given preferential access to the few available jobs. Yet despite the immense difficulties they faced, many of these early pioneers ultimately achieved a modicum of success. However very few did so by means of waged employment: instead most became pedlars, selling cheap clothing door-to-door, often in remote rural areas. Indeed their entrepreneurial efforts were so successful that by the early 1930s they began to send word back to home to their kinsmen, indicating that if they could find their way to Britain there would be able to earn and save far more than they ever could as peasant farmers back in Punjab - the region from which the great majority of seamen and soldiers had been recruited. Hence when hostilities broke out once again in 1939, small colonies of South Asian pedlars - the great majority of whom were of Punjabi origin - had established themselves most of Britain's larger ports, as well as in many of its major industrial cities.

\subsection{The post-war economic boom and its consequences}

Just as had happened two decades before, wartime labour shortages opened up all sorts of opportunities which had previously been closed to people of colour. Not only did many pedlars switch over to waged employment, especially in the munitions factories of central and northern England, but they were also joined by a significant number of ex-seamen whose ships had been torpedoed in the Atlantic, and for whom the shift from stoke-hold to foundry was relatively straightforward. Whilst the precise number of men involved (for the South Asian presence in Britain was then exclusively male) is hard to estimate, but is unlikely to have been much greater than a few thousand when hostilities ended in 1945.

At this point some sojourners took the first opportunity to return home: one such returnee who had a made a small fortune selling black-market nylons which his kinsmen serving on convoys had bought cheaply in New York told me how he had used his savings to buy a motor car from a departing sahib on the dockside in Karachi. Then he drove it all the way back to his village in District Mirpur, far to the north. His was a homecoming to be proud of! However many others decided to stay on, in the hope of reaping yet more benefits from their British environment. At first the going was extremely tough, just as it had been after the end of the first World War. However it was not long before the British economy not only picked 
up once again, and then moved into a period of sustained economic boom which turned out to last - barring a few temporary hiccups - right through until the end of the nineteen seventies.

Having found themselves in the right place at the right time, the pioneer sojourners promptly took advantage of these burgeoning opportunities. Not only did they move into the newly available jobs for themselves, but they also went out of their way to assist their kinsmen and fellow villagers to make their way to Britain. The result was an ever-expanding process of chain migration which enabled members of the third-world peasantry who were fortunate to live in and around the villages from which the early pioneers were drawn to gain direct access to waged employment in metropolitan Britain. To be sure they started right at the bottom of the industrial hierarchy, but nevertheless the hourly wages even in those jobs produced an income stream which was far higher than anything they could hope to tap into back home, especially if they were prepared to work twelve hours shifts six or even seven days a week as many did.

\subsection{Who were the migrants?}

Although the rapid growth of Britain's South Asian population set off by the resultant processes of chain migration was very much a function of the post-war economic boom, these macroscopic 'push' factors cannot begin to explain why it was that the vast majority of settlers were drawn from a few highly restricted areas in the subcontinent, or on how it came about that members of each of these groups have tended to follow ever more diverse strategies of adaptation since they arrived in the UK. In community-specific terms, the vast majority of Britain's current South Asian population can be placed in one or other of four broad categories. Firstly there are the Gujaratis, most of whom are drawn from coastal districts in Saurashtra and round into the gulf of Cambay: within a current population around three quarters of a million, roughly $80 \%$ are Hindus and the remainder Muslim. A second major category is composed Punjabis from the Jullundur Doab: within a current population of around half a million, $80 \%$ are Sikhs and the remainder either Hindu or Christian. Thirdly there is an even more substantial body of Punjabi Muslims: well over half a million strong for their numbers are currently growing very rapidly - around three-quarters trace their origins to the barani areas of Mirpur, Jhelum, Rawalpindi and Gujrat Districts, accompanied by numerous much smaller inflows from Chhach, Faisalabad, Lahore and so forth. Last but not least there are the Bangladeshis: with numbers currently approaching a quarter of a million, they are overwhelmingly drawn from District Sylhet in the far north-east. 
Each of these inflows has its own specific historical roots, which are particularly ancient in the Gujarati case. Trading links between the Gulf of Cambay and the Persian Gulf were established well over three millennia ago, and in the immediate pre-Imperial period Gujarat was a major centre for the manufacture of cotton textiles, a large proportion of which was exported - mainly by Gujarati merchants - to all quarters of the Indian Ocean, and later on to Europe (Chaudhury, 1990). But although its local economy suffered a severe setback when Lancashire-based engineers managed to mechanise Gujarati textile technology, the Gujeratis' entrepreneurial capacities remained undimmed. Hence when Britain began to open up its newly-acquired East African possessions in the early years of the twentieth century, the Gujeratis were ready and willing to make the most of new opportunities, whether as craftsmen and engineers, or as small-scale traders in the interior. But although many prospered in those roles (see Chapter $* *$ ), their status was swiftly undermined the East African colonial edifice collapsed during the course of the nineteen sixties. Whilst some of the settlers returned to India, the great majority took advantage of their formal status as British subjects to move onwards to the UK, where they received a ready welcome from enterprising kinsfolk who had already established a foothold cities such as Leicester.

By contrast the route by which the three other major components of Britain's South Asian population found their way to the UK conforms much more closely to the model set out in the previous section. Since the British Indian regiments posted to France during the first World War were largely recruited in the Punjab, the pedlar communities who provided the foundation for mass migration after the end of the second World War were largely composed of Punjabi Sikhs and Muslims. Meanwhile ex-seamen provided the bridgeheads around which two further communities - the Mirpuris from what is now Azad Kashmir, and the Sylhetis from north eastern Bangladesh, from where the vast majority of lascars serving in the British merchant navy were recruited - also began to establish themselves in the UK. Once the mass-transit system promoted by chain migration was in place, these four communities gained a near-monopoly of migratory opportunities within the British labour market. However much members of other communities rooted elsewhere in the sub-continent might wish to muscle in to these arenas, they were in no position to compete with the operators of these well-established networks. 


\subsection{Diversities in trajectories of adaptation and mobility}

The founders of all the major components of Britain's South Asian population shared many commonalities. Not only were virtually all of them of rural origin, and either peasant-farmers or craftsmen by trade, but very few arrived with any significant educational or professional qualifications. Yet despite their shared socio-economic background, members of each group - and even more so their British-born offspring - have followed sharply differing trajectories of adaptation and upward mobility as the years have passed.

In the very broadest of terms, Gujaratis, and most especially Gujarati Hindus who made their way to Britain via East Africa, have led the way upwards and outwards from the subproletarian position from which they all began, although the Punjabis from the Jullundur Doab - both Sikh and Hindu - were soon hot on their heels. Most members of the older generation used business enterprise as their stepping stone to success, usually starting with the ubiquitous corner shop, before moving on to establish much larger enterprises in either wholesaling, services or in manufacturing. Meanwhile a high proportion of their British-born offspring are achieving a spectacular degree of educational success. Law, Pharmacy, Accountancy and particularly Medicine are the preferred routes to upward mobility: no less than $20 \%$ of the places in Britain's medical schools are now filled by the children of British Asian (and very largely British Indian) parents.

But whilst the Gujaratis and the Doabi Punjabis have generally been spectacularly successful (although close inspection also reveals that upward mobility is still strongly conditioned by caste), members of other two major components of the South Asian population - namely the Mirpuris and Sylhetis - have (thus far at least) lagged some way behind. This is not to suggest that the Mirpuris and the Sylhetis have in any way 'failed': on the contrary it is plain that they have achieved a great deal. Hence a better way of putting it is that members of these communities have not, as yet, been able to carve out trajectories of upward mobility which are set at anything like as steep an angle as those now routinely being followed by their Gujarati and the Doabi Punjabi peers.

How, though, are these differentials to be explained? Although many observers are tempted to adopt the commonsense assumption that there will inevitably be a high degree of correlation between 'assimilation' and upward socio-economic mobility, the picture which is 
currently emerging is proving to be a great deal more complex. Indeed there are very good reasons for suggesting that although the concept of assimilation is much used in public discussion, the use of such a terminology is much more of a hindrance than a help when one sets out to explore the strategies of adjustment adopted by both settlers and their locally-born offspring have set about coming to terms with their British environment.

In the first place it goes without saying that settlers - and even more so their locally-born offspring - have been profoundly affected by their exposure to English social, cultural and linguistic conventions: indeed most members of the second generation are just as much at home in British as in South Asian cultural contexts. However cultural competence is in no sense a zero-sum game, such that the acquisition of the capacity to act and react appropriately in one arena precipitates, of necessity, a diminution of competence in others. Quite the contrary. A much more illuminating way of reading what has gone on is that members of Britain's South Asian communities have swiftly acquired a high level of bi- and indeed multicultural competence, such that they - just like members of all sorts of other similarly placed minority groups - are able to act and react appropriately in a wide range of differently ordered arenas. Hence whilst most British South Asians have now developed fluent capacity you participate in arenas exclusively organised according to the conventional expectations of members of Britain's dominant ethnic majority, this is in no way necessarily associated with an abandonment of their own ancestral roots, expectations and loyalties. Indeed it is precisely because the vast majority of settlers have continued to organise their domestic lives on their own terms that they have simultaneously managed to construct their most vital resource: the ethnic colonies which are now such a salient feature of the inner-urban environment through the length and breadth of the United Kingdom (Ballard 1994).

\subsection{The dynamics of adaptation}

Whist these 'little Indias' are undoubtedly partially rooted in emotional feelings of nostalgia, it would be a gross mistake to assume that this is the principal reason for their emergence. Rather they are much better understood as ethnic colonies, or in other words as active arenas for the articulation and development of a distinctive set of human, economic and conceptual resources. As such they are the prime source of the social, cultural, spiritual and psychological capital on the basis of which to launch an ever widening series of challenges to which their members would otherwise have be defencelessly exposed. But although resistance in this sense is very much the norm, such that all sections of the South Asian 
population have been able to make a substantial degree of progress since their arrival in the $\mathrm{UK}$, it is far from being a uniform phenomenon. Not only have the strategic objectives which members of each the many communities of which this broad population category is composed have set for themselves varied enormously, but so have the tactics they devised as they sought to reach them. As a result some very striking differences between the trajectories of mobility which each community has followed have now begun to emerge.

As is only to be expected these trajectories of mobility, grounded as they very largely are in the entrepreneurial exploitation of less well defended chinks in the established socioeconomic order, and further reinforced by the creative utilisation of their resources of moral, cultural, psychological and familial alterity, have many dimensions. On the economic front settlers have gradually moved away from the sub-proletarian occupations into which they were initially directed, partly in an explicit search for opportunities which brought more substantial material rewards, and partly because many of those jobs - in textiles and heavy engineering - simply disappeared in the midst of Britain's industrial holocaust in the early 1980s. Members of those communities which were already set on moving upwards and outwards, as were most of those Gujarati and Indian Punjabi origin were relatively little handicapped by these adversities. Not only had they already begun to diversify into all manner of small business enterprises - a trend which was now strongly reinforced - but their children were also doing well at school and college, from which an ever greater proportion now began to emerge with professional qualifications. This was also associated with parallel processes of residential mobility. Even before recession struck, many members of these communities had begun to move out of the decaying inner-city areas in which they had originally settled in favour of more attractive properties in the suburbs, where educational provisions were also of a much higher standard: as the 1980s progressed, this trend was yet further reinforced. Nor did mobility stop there. As young Asian professionals gradually began to realise just how seriously glass ceilings were likely to constrain their ambitions, more and more decided that the best solutions was to move onwards yet again - most especially to Canada and the United States. Not only did they find the constraints of racial and ethnic exclusionism to be much less severe on the far side of the Atlantic, but most were also able to take advantage plug into a ready-made network of ethnic conies which their kinsmen and caste-fellows had already begun to establish in North America. (See Chapters ** and **). Whilst it is extremely difficult to make an accurate estimate of the scale of such onward migration, a comparison of the results of the 1981 and 1991 Censuses suggest that the 
outflow during that period was in the order of 10,000 persons (virtually all of them 'Indian') per annum; moreover there can be little doubt that the scale of the outflow across the Atlantic increased substantially during the course of the following decade.

Yet although the settlers who ancestral roots lay in Gujarat and East Punjab overcame the obstacles with which they found themselves confronted with very considerable success although it is also worth noting that these patterns were in turn yet further conditioned by issues of religious, caste and sectarian affiliation - the trajectories followed by two further components of South Asian presence in Britain, namely the Potohari Punjabis from in and around the Mirpur region in Azad Kashmir, and Sylhetis from the far north-eastern corner of Bangladesh, have on the face of it been far less impressive. Not only have both these communities continued to increase very rapidly in size, partly because of their members relatively high fertility rate, and partly as a result of still on-going processes of family reunion, but in residential terms their members are still overwhelmingly confined to innercity areas, such that in numerical terms they actively dominate the localities which they have effectively colonized.

Yet although the communities into which they have consequently aggregated are in many ways even more tight-knit, and even more mutually supportive than those established by their Punjabi and Gujarati counterparts, the degree of educational and socio-economic mobility which 'Pakistanis' and 'Bangladeshis' have so achieved is a great deal less impressive than those of people whom large-scale data-collection exercises categorise as 'Indian' (see, for example, Modood et al 1997). Moreover it is precisely in those cities in the Pennine region of northern Britain where Mirpuri and Sylheti settlers have established ethnic colonies in which violent clashes between the members of these communities and the police erupted during the summer of 2001. Moreover the extent of the underlying differences are further underlined by two further factors. Not only have similar disturbances not erupted in those (usually much more suburban) areas where other sections of the South Asian population have now established themselves, but many Hindu spokesmen have gone out of their way to contrast the much more peaceful outlook of members of their own community in contrast to what they suggests are the innately violent proclivities of their much less reasonable and sophisticated Muslim counterparts. 
Just how much store should we put by arguments of this kind? That very significant differences have now emerged as between the various subsections of Britain's South Asian population is plain to see. How, though, are they to be explained?

\subsection{Islamophobia and cultural racism?}

In considering arguments to the effect that it is a commitment Islam which precipitates all manner of pathological behaviour, it is worth remembering that almost all the most enthusiastic articulators of that perspective within Britain's Hindu communities are also actively involved in the Vishwa Hindu Parishad, which is in turn closely affiliated with extreme nationalist - and hence strongly anti-Muslim - political movements back in India. In other words such arguments also substantially replay an ideological position which has largely been responsible for precipitating an ever-sharper degree of ethno-religious polarisation between India's Hindu majority and its Muslim minority. Given the context in which they were originally generated, loaded arguments of this kind clearly need to be treated with extreme care. Unfortunately, however, such arguments are grounded in a perspective which is closely congruent with (and which has to a significant extent been derived from) deep-seated European assumptions of the necessary inferiority of all things Islamic (Daniel, 198*, Ballard 1997). Hence there is a strong sense in which members of Britain's indigenous majority as well its Hindu minority all share a common commitment to Islamophobia. Indeed it is on this basis that Modood has argued that the principal cause of British Muslims' much more severe condition of relative deprivation as opposed to their Hindu and Sikh counterparts is the outcome result of their exposure to a virulently Islamophobic form of cultural racism.

Yet just how great is the explanatory force of such an argument? Whilst it is undoubtedly the case that anti-Islamic sentiments are even more deeply entrenched component of the British cultural tradition than they are in South Asia, there is little evidence that most members of the indigenous majority can accurately differentiate between South Asians who are Muslims and those who have other religious affiliation: indeed in the first instance they are all popularly identified as 'Pakis'. If so it seems most unlikely that potential discriminators preferential treatment of Hindu and Sikh South Asians as compared with their Muslim counterparts is the central source - or even a marginally significant source - of the marked differentials between the socio-economic achievements of members of these two broad population groups. This is not, of course to suggest that ethno-racial exclusionism is not a very significant handicap, but 
only that to suggest that its impact is likely to be broadly similar on members of both groups, and that we therefore need to look elsewhere in order to explain the observed outcomes.

\subsection{Social capital?}

With that in mind, alternative - and more plausible - explanations of these differences are no hard to identify. Whilst only a small minority of South Asian migrants arrived in Britain with technical and professional qualifications beneath their belts, so enabling them to compete (although with how much success is another matter) at much higher levels in the employment market, and although the vast majority who were of rural origin all shared the strengths of a broadly peasant outlook, it is now quite clear that the precise levels of prosperity which settlers enjoyed immediately prior to their arrival had a far reaching impact on the trajectories of adaptation which they subsequently followed. In this respect not only were the skills and competencies acquired by those who had spent some time in East Africa before moving on to Britain clearly a major adaptive resource, but levels of economic development in direct migrants' villages of origin also had a similar effect. Hence migrants drawn from areas with a long-standing history of agricultural prosperity, as in the case of the Jullundur Doab in Punjab, and the Saurastra region of Gujerat also found they had richer resources of social cultural capital - particularly in terms of educational experience and technical skills - than those who arrived from much less agriculturally prosperous (and so much less economically developed) areas such as Mirpur and Sylhet. This is not, of course, to suggest that Mirpuris and Sylhetis will consequently remain for ever handicapped as a result background, but only that they had a considerable amount of ground to make up as compared with their initially rather better equipped Jullunduri and Gujarati counterparts.

\subsection{Marriage rules and cultural capital}

Although such considerations go a long way towards explaining current variations in trajectories of adaptation and mobility as between differing sub-sections of Britain's South Asian population, it is by no means the end of the story. There are also some very significant differences in the cultural capital on which settlers have drawn in implementing their strategies of ethnic colonisation, many of which are rooted in the apparently wholly arcane sphere of marriage rules. Stated baldly, there is a sharp difference between the marriage rules followed by Hindu and Sikh migrants, all of whom practice rules of gotra exogamy, and those deployed by their Muslim counterparts. Amongst the latter not only are cousinmarriages permitted, but amongst the Pakistanis, and most especially amongst the Mirpuris, 
such marriages are actively preferred, so much so that over $60 \%$ of all Mirpuri marriages are contracted between first cousins.

What significance might all this have? Leaving the issue of migration wholly to one side for one moment, the practice of gotra exogamy has two major consequences. Firstly families have no prior obligations with respect to either making or accepting offers of riste once their offspring reach marriageable age: on the contrary they can make their choices relatively freely within the limits of the endogamous jati; secondly the fact that all marriages are arranged in this way not only means that agnates (those to whom one is related by descent) and affines (those two whom one is related by marriage) form two quite separate and nonoverlapping social categories, but also that each family, and indeed each individual within each family has links with a wide range of ristedar affines who are spatially scattered across a number of neighbouring villages. By contrast where frequent close-kin marriage is not just permitted, but is the actively preferred option, that distinction is almost entirely eliminated. As a result kinship networks are not only much more tightly in-turned but are also very much less spatially extensive.

However my concerns here are not so much with what consequences these differences in kinship structure have had within their immediate South Asian context, but rather with the impact which they have had not just on processes of migration and resettlement, but also on their users' subsequent trajectories of adaptation and socio-economic mobility. In an earlier paper (Ballard 1990) I discussed at some length how it was that these differences went a very considerable way towards explaining why it was that Pakistanis in general, and Mirpuris in particular not only delayed reuniting their families in Britain for very much longer than did Jullunduri counterparts, but also why it was that Mirpuris also tended to form far more tightknit, in-turned, and hence socially and culturally conservative communities than did their Jullunduri - and indeed Gujarati - fellow-migrants. In other words these differences in the precise characteristics of the cultural capital on which members of these two broad categories drew - and are indeed still drawing - have yet further reinforced the differential impact of the differences in social capital which were outlined in the previous section.

Once one takes all these issues into account - and unfortunately there is no space to explore all their many ramifications within the constraints of this Chapter - the almost wholly deprivationist view which is implicit in Modood's concept of cultural racism can very largely 
be put to one side. Although undoubtedly subjected to ethno-racial exclusionism, all South Asian settlers in Britain - whatever their specific community affiliation - are not just active agents in their own cause, but are making maximum use of whatever forms of social, cultural, technical, economic, educational and cultural capital to which they have access. There is no better route to upward mobility. But to the extent that the precise character of those assets varies as between all the many subsections of this population, so - as is only to be expected their trajectories of adaptation are similarly diverse. With this in mind it follows that the deliverers of public services (from the Police onwards) to Britain's Mirpuri and Sylheti communities such a challenging task not so much because of their perverse refusal to assimilate - as is commonly supposed - but rather because they are making particularly intensive use of their ancestral cultural capital as they build new lives for themselves in Britain. To be sure as recent events in Oldham and Bradford have very clearly shown, many members of Britain's indigenous majority strongly resent their use of very public strategies of alterity; but as the police discovered to their cost, concerted attempts to ignore - and thus to suppress - such plurality by imposing a policy of zero tolerance are invariably entirely counter-productive. Whether in the riot torn Pennine region, or in much more prosperous cities such as Leicester and Southall in which Gujarati and Jullunduri settlers are much more salient, Britain has yet to wake up to the pluralizing consequences of South Asian strategies of ethnic colonisation.

\section{Transnational connections}

Whilst it is now becoming increasingly obvious that the consequences large scale migration from Britain's former Imperial possessions in South Asia have been much more far-reaching than most commentators - committed as most of them were to assimilationist expectations ever appreciated, the impact of these processes of colonisation 'from below' are by no means restricted to Britain. On the one hand they are part of a much more global phenomenon in which the transnational networks 'from below' are steadily transforming the structure of the post-colonial world order, and on the other they are also having a far-reaching impact on migrants' countries, regions and villages of origin.

\subsection{The dynamics of transnational networks}

Migration invariably precipitates transnational networks, which operate in at least two distinct but mutually complementary ways. In the first place the process of chain migration to which such networks give rise a kind of long-distance escalator which enables those who are 
in a position to step on to them can thereby be transported out of the positions of relative poverty in which they would otherwise have been confined, and to take advantage of the radically enhanced patterns of opportunity available elsewhere. When the lower end of the escalator is located amongst very small-scale peasant farmers in the third world, whilst the upper end reaches into a metropolitan city in the developed world, the advantages which accrue from stepping aboard are immense, and lead quite directly to what the British authorities describe as "the pressure to migrate".

However each of the networks which support these counter-hegemonic entrepreneurial flows also have a much more complex internal dynamic of their own. Whilst the prospect of gaining access to sharply higher material opportunities elsewhere may be the proximate cause of stepping aboard such escalators - be they peasant farmers or software engineers - do not thereby leave their pasts behind them. Quite the contrary: they remain tied to their family and kinsfolk back home through they very same networks of reciprocity out of which the escalator itself is constructed. The consequences of all this are far-reaching. Not only do almost all migrants initially assume that their departure is but a temporary phenomenon (even if they subsequently find themselves taking up much more permanent residence overseas than they had ever expected), but no matter how long they stay abroad, most also retain strong feelings of obligation and loyalty to their kinsfolk back home. Hence migrants typically remit a substantial proportion of their earnings during their initial period of overseas residence, which are usually deployed in such a way as to improve the living standards, as well as the social standing, of their family back home. In so doing the typical initial investment is the construction of a new, improved, and above all prestigious family residence, followed by (although it is often a poor second) by investment in such things as additional agricultural land and machinery, providing a substantial dowry for their unmarried sisters and sponsoring public rituals and shrines. But although these remittance inflows frequently have a farreaching impact on the character and structure of the local economy, especially when chain migration results in a significant proportion of the local population in a specific area moving overseas, the long term consequences of these developments can be extremely varied.

\subsection{Family reunion and its consequences}

One of the most important determinants of the resultant outcomes is the stability of the inflow of migrant remittances over time, which is in turn largely a function of migrants' strategies of family reunion. The reasons for this are quite straightforward. In rural contexts most extended 
families first dip their toes into the water by sending one or more of their younger male members overseas, in the expectation that they will remit a substantial proportion of their earnings back home. However this arrangement is inevitably unstable in the longer run, since the migrants are thereby separated for long period not just from their wider extended family, but above all their wives and children. However as soon as such migrants decide to call their wives and children join them overseas, as (visa restrictions permitting) they almost invariably eventually do, the proportion of their earnings which they are in a position to remit inevitably drops sharply. When this occurs on a substantial scale - for such changes in family policy tend to occur in waves - the sudden drop in remittance flows invariably has much more than merely domestic consequences, since such developments swiftly puncture the remittancedependent booms which are invariably generated at the far end of such transnational linkages.

Yet this is by no means necessarily the end of the story. In the first place it is often the case that once the initial wave of migrants have secured their own and their family's position within the ethnic colonies which they have begun to construct around themselves overseas, they may once again begin to generate a surplus which makes investment back home a realistic possibility. Secondly, and just as importantly, there is the question of just where and on what basis they choose to organise their childrens' marriages.

\subsection{Marriage strategies}

In the immediate aftermath of migration, most migrants' marriage strategies are quite straightforward: they continue to make ristes for their children on exactly the same basis, and with just the same kind of status-inspired objective in mind, as they would have deployed had they stayed at home. As a result the vast majority of early settlers' children's marriages were arranged and celebrated not in the diaspora, but in the immediate vicinity of migrants' ancestral villages. Doing so not only enabled these pioneer entrepreneurs to cash in their global achievements for local prestige (Gardner, 1995), but also facilitated the entry of evergrateful sons- and daughters-in-law into the UK.

In the longer run, however, the potential contradictions inherent in matches arranged in this way tend to become steadily more salient. When one partner (and especially the female partner) had been born, raised and educated in a metropolitan context, then however attractive a riste may have seemed to their parents, most of whom continued to operate in home-village terms, there was nevertheless a strong prospect that their offspring would view 
the person with whom they were being hitched up as little more than an unsophisticated rural hick who is wholly unable to keep her (and more especially his) end up either socially or economically in a European context. Given their unpropitious foundations, such matches frequently ran into difficult; worse still a significant proportion began to collapse in mutual acrimony.

Whilst parents were often angered and perplexed by these developments, their offspring were only too well aware of the underlying contradictions: hence they began to mount ever more pressing campaigns to persuade their elders to change their marriage strategies. Significantly enough, few suggested that customary preferences for caste endogamy and so forth should be completely abandoned; rather they urged their parents to make much more active attempts to seek out ristes within the ethnic colonies which were growing up overseas, rather than automatically putting out feelers back home.

However the outcome of these efforts have been far from uniform, for the younger generation's success in introducing these reforms has turned out to be heavily dependent on the character of the marriage rules conventionally deployed with the community to which they belonged. Where the choice of riste is relatively open - as it is in the case where gotra exogamy is the norm - it was very easy for parents to redirect their search towards a diasporic arena. Since they had no prior obligations to offer such riste in any given direction, they did not disappoint anyone in particular by so doing. However in systems where there is cousin marriage is the norm, such that brothers and sisters expect to be given priority in the arrangement of riste between each others children, the reverse is the case. Not only do migrants' close kin back home take it for granted that their offers of riste should be accepted as a matter of principle, , on the grounds firstly that they have a right first refusal with respect to such a match, and secondly that those who have been fortunate enough to establish themselves overseas have a powerful moral obligation to assist their nephews and nieces take that crucial first step onto the escalator. In these circumstances young people's protests that the relationship might not work out are much more likely to be buried in the face of overwhelming feelings of wider family obligation - and thus to be over-ridden.

\subsection{The construction of transnational networks in an exogamous context}

By the end of the nineteenth century Sikh and Hindu entrepreneurs from the Jullundur Doab had begun to establish themselves in a number of overseas destinations, including Singapore, 
Hong Kong, British Columbia and East Africa. To this day evidence of their success is still readily visible in their home villages in the form of crumbling palaces still showing the last remnants of the colourfully decorated stuccoed faced in the prestigious styles typical of the early twentieth century. As one walks through such villages careful inspection allows one to identify a whole succession of different building styles, firstly those which feature much larger modern bricks in the British colonial style, then those which make increasingly extensive use of reinforced concrete, until one eventually reaches recently constructed kothis featuring marble floors and elaborately pillared balconies. However what is particularly striking about all these buildings, regardless of their age, is that they rarely appear to have been lived in for very long. Invariably built in what was the height of fashion in their time, they appear above all to have been constructed as very public markers of their builders' overseas achievements; but to the extent that it was only possible for emigrants to finance such initiatives relatively late in life - by which time their wives and children had most usually joined them overseas - these palaces rarely formed the principal focus of their owners' extended families' domestic activities.

But whilst this provides the clearest possible evidence that most migrants adopted an overseas domicile relatively quickly, that certainly did not mean that their transnational linkages had come to a swift end. Far from it. On the one hand these elaborately constructed palaces were a very public statement that still cared a great deal about their status and reputation back home, no matter how extended their absence overseas may have been. Secondly their fellow villagers were themselves keen to keep those links open - for without them they would lose the opportunity to place their own offspring on the escalator to metropolitan prosperity. During the early phases of Jullunduri emigration, during which migrants' most favoured destinations lay in East Asia, East Africa and the West coast of North America, most of those involved still preferred to arrange their children's riste back home in Punjab, which could be elaborately celebrated in those carefully constructed palaces.

But although this pattern was also sustained during the initial phases of settlement in Britain, by the early nineteen seventies some radical changes began to take place. Thanks to the availability of substantial numbers of potentially suitable partners in the UK, together with growing pressure from young people themselves, a shift of strategy began to take place. As we saw earlier, an ever-increasing number of riste began to be arranged within the overseas arena. However what is also very striking about these developments is that they soon ceased 
to be constrained by national boundaries. Although still overwhelmingly caste-specific, the Jullunduri marriage market soon became global in character, reaching out to Singapore, Hong Kong, Kenya, and above all to North America. Kinship networks had not only become global in scope, but to the extent that matches which spouses with spouses based in India came to be regarded as a fall-back option which was only seriously considered when a suitable arrangement could not be made in the diaspora, the whole edifice was steadily disconnecting itself from its Punjabi roots, and in that sense moving further and further 'offshore'. That process continues with some vigour - particularly amongst young well-educated professionals - to this day.

\subsection{Close kin marriage and the construction of transnational networks}

Unlike Jullundur, Mirpur does not lie in the easily irrigable plains of Punjab, but at the point where the Potohar plateau runs into the outer foothills of the Himalayas, just to the east of the river Jhelum. Whilst a good deal more densely populated - at least in terms of persons per cultivable acre - than Jullundur, so the mean size of each family's holdings is, and always has been, very much smaller. Moreover Mirpuris also suffered from a further disadvantage: their incorporation into the Princely state of Kashmir, whose rulers were notorious for imposing high taxes on their subjects, whilst providing a much lower level of public services than those available in neighbouring Districts in British India. Against all this Mirpur has only one positive environmental advantage: its close proximity to the mountains of the Pir Panjal means that the District receives a high and largely reliable rainfall. Given all this, not only has Mirpur's population always been a good deal less prosperous than Jullundur's, but its members have had - and still have - access to many fewer infrastructural resources. Yet despite all these disadvantages the Mirpuris have become even more extensively involved in transnational activities than the Jullunduris, even if the consequences of that engagement has precipitated some rather different outcomes.

Mirpuris have a long history of involvement in translocal employment, since the crews of the river boats which handled Punjab's trade with the Indian Ocean had long been recruited from this area, as well from the Chhach District, located some fifty miles to the west on the banks of the river Indus. However the 1880s saw two parallel developments: first the construction railway links from both Karachi and Bombay into the interior of Punjab (which immediately undercut river transport in terms of both cost and speed), and secondly the British merchant navy's switch from sail to steam. However European seamen were most unwilling to work in 
the stokeholds of the new ships, especially in tropical conditions, so opening up an alternative source of employment for redundant Mirpuri and Chhachi boatmen. They jumped at the chance, and soon gained a virtual monopoly over stokehold jobs on merchant ships operating out of Karachi and Bombay - a position which they managed to sustain until oil finally replaced coal after the end of the second world war.

But although Mirpuri and Chhachi seamen therefore had a lengthy experience of transnational movement, very few looked beyond the niche which they has secured within the global labour market. Hence whilst a few men jumped ship in search of better opportunities ashore in cities from London to Sydney and all points in between, the great majority appear to have preferred to serve out their contracts on board ship, and take their savings back to their villages in the Punjab at the points where the rivers Jhelum and Indus emerge into the plains from the northern mountains.

Although mass-migration from Mirpur to Britain was no less a product of the post-war economic boom than was the parallel inflow from Jullundur, its dynamics turned out to be very different. Although a very small number of Mirpuri seamen had established themselves in Britain prior to the 1939, their presence was significantly boosted in the years that followed as sailors who had had their ships torpedoed from beneath them were drafted to work in Britain's labour-starved foundries and munitions factories; moreover their numbers when coal-fired ships were phased out during the late 1940s, when employment in industrial Britain provided a welcome alternative to now-redundant stokers. But if Mirpuris established their beach-head in Britain, on a distinctive basis, the subsequent rapid growth in the scale of their presence was not: just as with the Jullunduris, there was acute demand for their labour. To be sure wages on offer were extremely low by British standards, and the jobs available were largely confined to the night shift; but from a Mirpuri perspective they offered anyone prepared to work long hours (12 hour shifts 6 days a week were commonplace) an excellent opportunity to earn and save.

Nevertheless the Mirpuris set about making the most of these opportunities in a very different way from their Jullunduri counterparts. Whilst most of the latter set about reuniting their families in Britain with a year or two of arriving, most Mirpuris preferred to make regular visits back home. Hence may pursued a strategy of inter-national commuting for one or even two decades before they at long last brought their wives and children to Britain. Hence it was 
not until the late nineteen seventies that family reunion became at all commonplace, and it took well over a decade before that process was anywhere near complete. took well over a decade to complete. At the same time Mirpuris had also begun to devise some very effective strategies by means of which to subvert the deliberate exclusionist objectives of Britain's immigration laws.

\subsection{The Mangla Dam, employment vouchers, and cousin marriage}

Britain's first formal effort to halt the inflow of non-European labour was the Commonwealth Immigration Act of 1992, which required unskilled workers from South Asia and the Caribbean to obtain employment vouchers before entering the UK. But despite its exclusionist objectives, the scheme's initial impact was quite the opposite effect, particularly with respect to the Mirpuris. It is easy to see why. On the one hand the construction of Mangla Dam across the river Jhelum - which was completed in 1966, and which flooded most of Mirpur's most fertile land - led to a sudden intensification of the pressure to migrate. In the absence of established transnational connections those affected would have had little alternative but to go along with the Government of Pakistan's grossly inadequate offers of compensation and resettlement. By contrast moving on to Britain was a far more attractive option - always provided one had the necessary kinship connections. The procedure was achieved was relatively straightforward. Textile mills in Yorkshire and Lancashire were still acutely short of labour, and foremen and personnel managers found the new rules a godsend. Mirpuris already working in the mills regularly enquired as to how many extra hands were needed, and promised that if the requisite vouchers were issued, new workers would be ready to fill those slots within the month. Chain migration was consequently directly reinforced. However this window of opportunity did not remain open for very long. Less than three years later the voucher scheme was put into abeyance on the grounds that it was being 'abused'.

Even so the Mirpuris still had a number of other tricks up their sleeves. In the late sixties the Mirpuri presence in Britain was still overwhelmingly composed of adult males who had left their wives and children back home in their villages of origin, and whom they repeatedly visited at intervals of a couple of years or so. But as de facto British citizens, they were entitled to reunite their families in the UK. This precipitated a further set of cat and mouse developments. Established settlers' most immediate response to the end of the voucher scheme was to exercise their right to call over their near-adult teenage sons (and/or their nephews whom they represented as their sons) to the UK, so that they could start work in the 
mills as soon as they reached the age of 16 . But although the immigration authorities sought to close that loophole by insisting that settlers should call over their entire family, including their wives and daughters rather than just their teenage sons if they wished to implement their rights of family reunion, this also soon backfired. As the years passed the impact of the migrants' earlier strategy of transnational commuting on the quality of family life had grown steadily more severe, and they were by now much more ready to go along with the immigration authorities' demands. Hence far from restricting the inflow, the new rules led especially amongst the Mirpuris - to a further increase in the scale and the permanence of settlement.

Nor did the process end there. When British-based Mirpuri began to arrange riste for their offspring, their initial preference was just the same as the Jullunduris: to set up matches on just the same basis as they would have done in the absence of migration. However whilst the Jullunduris soon switched towards seeking out suitable riste within the diaspora, Mirpuris found themselves much more tightly constrained - thanks to the strength of their ideological commitment to close kin marriage - to fulfil their obligations to those of their siblings who were still based back home in Mirpur, and thus to continue to arrange their childrens' riste accordingly. Hence whilst the British immigration authorities have made great efforts to stop settlers using marriages arranged on this basis to power the operation of now well-established escalators between rural Mirpur and the ethnic colonies which settlers have established in a whole host of industrial cities in Britain, their efforts have been largely unsuccessful. At least half (and possibly as many as two thirds) of the marriages currently being contracted by young British-based Mirpuris are still arranged with their cousins from back home. Although these outcomes - which serve to illuminate the success with which Mirpuris have been able to subvert all the efforts of Britain's immigration authorities to halt their inflow - are by no means solely a result of strength of their culturally grounded commitment to close kin marriage, they nevertheless stand in sharp contrast which have taken place within those groups (of whom the Hindu and Sikh Jullunduris are but a specific example) whose marriage rules include a commitment to descent-group exogamy.

\section{Transnational entrepreneurship and the subversion of the post-Imperial order}

Whatever additional objectives South Asian emigrants may have had, improving their own material conditions, as well as those of other members of their extended families and their as yet unborn offspring clearly lay close to their hearts. Just how far have they managed to 
achieve that goal? In broad terms the answer is now very clear. Despite the positions of relative disadvantage within the subcontinent from which most of them began, and the despite the very substantial obstacles they encountered as the pushed their way upwards and outwards through post-Imperial socio-economic order, they have met with a very substantial degree of success. Not only have substantial numbers of settlers managed to penetrate the exclusionary bastions which every country in the metropolitan swiftly erected around itself, so enabling them to tap into the much wider range of opportunities available there, but the success of their entrepreneurial activities has also precipitated far reaching economic changes in their villages, regions and countries of origin. However the precise scope, character and consequences of those changes has been almost as varied as the trajectories of adaptation which settlers and their offspring have pursued overseas - and for much the same reasons.

Yet just what can be said by way of conclusion about the causes of these differentials - let alone of their consequences?

\subsection{The local in the global: transnational entrepreneurial strategies in context}

In considering the numerous studies which suggest that the Mirpuris are still amongst the poorest of all the various South Asian communities which have now established themselves in Britain, and that their children are the least educationally successful, three salient factors are worth bearing in mind. Firstly the low level of economic development, and especially the lack of infrastructural resources - most particularly in terms of education - in their villages of origin. Secondly the tight-knit character of the kinship structures which are precipitated by their globally-unprecedented commitment to close kin marriage; as a result the Mirpuris' commitment to the export of human capital along the escalators of chain migration has been sustained for very much longer, and organised to a much higher level of sophistication than within almost any other South Asian groups. Thirdly these kinship structures have also had a far reaching impact on the way in which status seeking - an all-consuming South Asian priority - is conducted. As a result Mirpuris routinely find themselves driven to engage in ever more byzantine counter-manoeuvres in an effort to contain and subvert the efforts of their closest kin to advance their own interests, whilst the much more geographically dispersed and open-ended networks of those groups who marry exogamously ensures that their efforts to keep up with their rivals - be they Singhs, Kapoors, Mistris or Patels - pull them outwards into participation into much social arenas which by moved substantially offshore. In the light of all this it is small wonder that groups whose members had the good 
fortune to arrived in Britain with much more extensive social, technical and educational capital than the Mirpuris, and whose kinship structures actively encouraged the elaboration of translocal linkages followed trajectories of upward mobility which were set at a much steeper angle than that achieved by the Mirpuris.

However simply to cast the Mirpuris as 'failures' would be a gross mistake. Not only did they start the race with substantially greater handicaps than many of their peers drawn from elsewhere in South Asia, but they also chose to follow a significantly different course whilst running it. It all depends on one's yardstick for 'success'; whilst dramatically fewer Mirpuris may have gained professional qualifications, or moved upwards and outwards from the innercity areas in which they initially established residential colonies than their Jullunduri or Gujerati counterparts, they have nevertheless been far more successful in subverting one of the principle instruments whereby structures of global inequality are sustained in the contemporary post-Imperial world: immigration control. Of course this has only occurred on an intensely localized basis, but as a result of their thoroughly subversive entrepreneurial efforts, well over 50\% of Mirpur's population have by now managed to establish themselves in the metropolitan world: there is no way in which this achievement can be gainsaid.

This also raises a further questions about the spatial context in which such yardsticks should be applied, for once a body of people have gone transnational, it inevitably follows that yardsticks of success should be adjusted appropriately. Hence, for example, whilst numerous commentators have expressed extreme concern about the very low incomes as well as the poor standard of housing which Britain's Mirpuri and Sylheti communities have enjoy, very few have sought to establish on what scale members of these communities are continuing to remit a substantial portion of their income back to the subcontinent, or the extent to which they have access to a second set of residential facilities in that context. Once one does take such issues into account, the whole picture changes dramatically. No wonder: one of the migrants' central in penetrating the obstacles designed to exclude them from the metropolitan world was to boost their families' status at their point of departure. Not surprisingly, they have also achieved a considerable degree of success in this arena, although once again to differing degrees, and with markedly different consequences. 


\subsection{Kinship and remittances}

As we saw in the case of the Jullunduris, most migrants invested heavily in refurbishing the houses in which the remainder families still lived, and when the time was ripe - usually towards the end of their employment career - many built vast palaces to mark their achievements. However to the extent that exogamous groups were moving their domicile steadily offshore, most of these palaces were actually utilised much less than their builders had hoped an expected. The same was broadly true of their investments in agricultural land and machinery with which to farm it. Although substantial profits could be reaped from such investments, most especially in agriculturally prosperous areas such as the Jullundur Doab, their increasingly well qualified offspring had no interest in supervising operations on their ancestral holdings: if and when they did take trips India they were soon far more interested in visiting Agra or Goa than some village out in the sticks in Punjab. Land and houses were rarely sold whilst members of the older generation who had grown up in the village were still alive. That would have been altogether too shameful. However once they had passed away their offspring usually disposed of those once-cherished assets at the earliest possible opportunity.

In the Mirpuri case the pattern of remittances was rather different. Given that they moved much more slowly towards family reunion, lone Mirpuri males working in Britain remitted the greater part of their earnings for a much longer period than their Jullunduri counterparts: house building therefore proceeded on a much more elaborate basis, and precipitated a huge boom in the local construction centre. However as a result of the combination of low levels of productivity in local agriculture, lack of basic infrastructural support, and the huge degree of wage inflation in the local labour market which was precipitated by the inflow of migrant remittances, agricultural investment - as opposed to speculation in land - brought no significant profits. Hence once spectacular new houses had been constructed, most families simply placed their excess funds on deposit in the bank. By the late 1970s, the local economy in Mirpur was already following a very different trajectory from that in Jullundur. Although capital-rich, Mirpur's superficial prosperity was grounded in a high level of dependency on the continuing inflow of remittances. Meanwhile in Jullundur those self-same inflows served a very different purpose: to add gilt to the gingerbread of an already thriving local economy. 


\subsection{Development or dependency?}

Given all this, I found myself driven to adopt some very pessimistic conclusions when I first began to take a comparative interest in economic developments way back in the nineteen eighties. Acute economic recession in the United Kingdom, which had a particularly severe impact on the Mirpuri community, had led to a sharp decline in the volume of migrant remittances; meanwhile the condition of virtual civil war which erupted in the aftermath of the Indian Army's disastrous attack on the Golden Temple in Amritsar ensured that members of the Sikh diaspora entirely lost interest in investing back home. However the impact of these developments in each area were very different. Whilst the Jullundur Doab may have suffered as a result of the loss of the gilt from its gingerbread, let alone the disastrous consequences of nearly a decade of civil war, its agricultural prosperity was largely unaffected. By contrast the Mirpuri economy appeared to be in much more serious difficulties. Agricultural productivity had already declined so far that the District had already lost the capacity to be self-sufficient in food grains, and the superficial prosperity generated by the construction boom of the late nineteen seventies had very swiftly faded. The local (and national) economy was in the midst of a severe, and apparently unstoppable, downward spiral (Ballard 1982, 1987).

However a visit to Mirpur in the first year of the new millennium has demonstrated that such gloomy expectations were mistaken - at least in the short run. At least on the face of it, the Mirpuri economy has gone from strength to strength. A rash of new buildings, some as many as five or six stories high, have erupted both in the villages and the towns: those which were constructed in the nineteen sixties and seventies have been left entirely in the shade. There are numerous cars an the roads as well as teeming shoals of motor cycles; and the bazaars in the District's qasbahs now boast 'Plazas', two-story off-street shopping malls selling all manner of consumer goods, whilst the sewing machines of whole streets-full of tailors literally hum with industry.

Yet there are many ways in which all these outward signs of remittance-inspired prosperity are wholly misleading. Most of the grand houses turn out, on closer inspection, to be uninhabited: their owners have simply locked the doors and returned to England. Most also turn out to largely empty, with the exception of a single room which has been hurriedly kitted out to entertain guests. Moreover the architectural styles in which they are constructed are 
most revealing. Most residential properties in Pakistan - including those in the nearby capital city of Islamabad which is entirely reserved for the elite - are invariably concealed behind high walls. Domestic space is very emphatically private. However the new houses going up in Mirpur almost entirely ignore these conventions. At present two styles of architecture appear to be in particular favour. The first can best be described as the sky-scraper pattern: multi-storied buildings which are frequently adorned with all manner of glossy decorations. However the fact that even in the countryside such buildings are often clustered together in groups where each successive construction is marginally taller than its predecessor provides the clearest possible indication that it is not the high cost of land which drives these developments. The second architectural style, which can best be described as overblown neoclassical, featuring with vast balconies and pillared porticoes, together with elaborately decorated stuccoed gable ends further confirms the logic of the whole exercise. In the first place these are not machines for living in, but rather a very public means of expressing their builders' personal achievement; secondly the audience to which these expressions are directed is not the world at large, but rather at their own immediate kin who have stayed back in Mirpur, as well as at their fellow emigrants' house just down the road whose splendour has been outshone by the new erection. An elaborate game of status competition is being played here - and very little else.

Even so the newly-revived construction boom, which in turn supports a large service sector in terms of brick-kilns, steel and cement distribution, let alone the largely-immigrant labour force which actually responsible for building these palaces, is by no means the only sphere of the local economy which has been boosted by the spending of returnees. Just as significant is the growth of bazaars and plazas supporting myriad small shop units which provide readymade clothes, shoes, tableware, and host of western-style food items from Cornflakes to Nescafe to families making brief visits back home to celebrate their sons' and daughters' riste. In other words this is all very much a migration-specific phenomenon: there is little or no demand for such goods in nearby rural areas which lack Mirpur's intense transnational connections. Thus in sharp contrast to Jullundur, where returnee spending only gives a relatively small boost to an already-thriving local market for such domestic products of this kind - the greater part of economic activity in Mirpur is predicated around the continued inflow of funds from overseas. It follows, therefore, that if this inflow were to cease - for whatever reason - the consequences for the Mirpuri economy would be dire. 
Whilst Mirpur's success in people-export has undoubtedly generated a gloss of affluence, its underlying economy - which has always been grounded in small-scale peasant farming - has been left almost untouched. Hence whilst it is easy enough to be impressed by the rash of newly constructed houses and dramatic developments in the major bazaars, Mirpur's real as opposed to visitor-fuelled - economy is still overwhelmingly agricultural. However in sharp contrast to Jullundur there has been no significant investment in agricultural machinery, or in the tube-wells and pump sets which would facilitate the production of high-value horticultural crops which would find a ready market in nearby Islamabad. Instead the local economy but become locked into a condition of dependency on its transnational linkages. Hence few young people in Mirpur look forward to a local future: instead the vast majority eagerly await an offer of riste from their kinsfolk overseas, and are vastly disappointed if it fails to arrive. A wry comment from one informant summed the situation up with some clarity. 'We don't cultivate wheat here any more', he told me, 'we cultivate visas instead'.

\section{Conclusion: the dynamics of transnationalism}

Just how can we best set about making sense of the complex and frequently paradoxical outcomes of the diverse forms of post-Imperial transnational entrepreneurship, of which it has only been possible to explore a very small portion within the limited confines of this Chapter? Whilst the developments outlined here offer very largely contradict the pessimistic and largely determinist conclusions of the greater part of late twentieth century European (and broadly 'Marxist') sociology, the wise words of the Master himself provide an acutely perceptive signpost as to how these developments might best be understood. As he puts in the opening sentences of the Eighteenth Brumaire, "Men make their own history, but they do not make it as they please; they do not make it under self-selected circumstances, but under circumstances existing already, given and transmitted from the past"(Marx, 18*****) Of course there was much that was missing from Marx' vision, writing as he was from a mid nineteenth century Eurocentric viewpoint: not only did he grossly underestimate the revolutionary potential of cultural alterity, but he had little comprehension of the sociopolitical dynamics which would ultimately shape our contemporary post-Imperial world.

Nevertheless it is quite clear that transnational entrepreneurs from South Asia, just like innumerable others drawn from every corner of the global periphery, are making history: however limited their achievements may yet have been, they are nevertheless beginning to undermine the established structure of the global order. But although it follows that they 
could not do so entirely as they pleased, nor under wholly self-selected circumstances, such that they had to rely on chinks in the system opened up by chance contingencies, entrepreneurial activists 'from below' continue to exhibit an immense amount of creativity as they set about making the most of the resultant opportunities. Yet although he was acutely aware of the importance of agency, and of the human capacity to act on their own terms in order radically to change their circumstances, there was point on which Marx was grossly mistaken. In keeping with nineteenth century ideologies of progressivism, he assumed that ancestrally generated cultural assumptions would always be a handicap in the articulation of such processes. As the multiple dynamics of transnationalism described in this Chapter - and indeed throughout this volume - dramatically demonstrate, Marx and most of his followers' assumptions need to be turned on their heads: it is precisely by creatively utilising the resources of their ancestral traditions - whatever format that they might happen to have - that south Asian transnational entrepreneurs have achieved so much.

\section{BIBLIOGRAPHY}

Adams, C., (1987) Across Seven Seas and Thirteen Rivers London: THAP

Ballard, R (2002) "The Impact of Kinship on the Economic Dynamics of Transnational Networks: reflections on some South Asian developments" in

Ballard, R (2002) "Progress? But on whose terms and at what cost? The paradoxical consequences of successful transnational entrepreneurship", in

Ballard, R (1999) The Socio-Economic Educational Achievements of Britain's Visible

Minorities http://www.art.man.ac.uk/casas/Papers/mobility.doc

Ballard, R (1999) The Demographic Characteristics of Britain's Visible Minorities

http://www.art.man.ac.uk/casas/Papers/demography.doc

Ballard, R (1996) "Islam and the Construction of Europe", in Shadid, W.A.R. and van

Koningsveld, P.S. (eds.), Muslims in the Margin: Political Responses to the Presence

of Islam in Western Europe, Kampen: Kok Pharos

Ballard, R (1994) Desh Pardesh: The South Asian Presence in Britain. London: C.Hurst and Co.,

Ballard, R (1992) "New Clothes for the Emperor? The Conceptual Nakedness of the British Race Relations Industry" in New Community Vol. 18

Ballard, R (1990) "Migration and Kinship" in Clarke, C., Vertovek, S., and Peach, C., South Asians Overseas: Contexts and Communities Cambridge, CUP 
Ballard, R (1989) "Overseas Migration and its Consequences: the case of Pakistan" in Hamza Alavi and John Hariss (eds) The Sociology of Developing Societies: South Asia London: Macmillan.

Ballard, R (1988) "The Political Economy of Migration: Pakistan, Britain and the Middle East", in Eades, J. (ed.), Migrants, Workers, and the Social Order, London: Tavistock. Ballard, R (1983) "Emigration in a Wider Context: Jullundur and Mirpur Compared" in New Community, Vol 11.p 117 - 136

Berthaud, R (1988) The incomes of ethnic minorities. York : Joseph Rowntree Foundation Bhachu, P (1985) Twice Migrants: East African Sikh settlers in Britain London, Tavistock Chaudhuri, K. N. (1990) Asia before Europe: Economy and Civilization of the Indian Ocean from the rise of Islam to 1750: Cambridge: Cambridge University Press.

Dhaya, B. (1973) “The nature of Pakistani Ethnicity in Industrial Cities in Britain” in Cohen, A (ed.) Urban Ethnicity London: Tavistock

Gardner, K (1995) Global Migrants, Local Lives, Oxford, Oxford University Press

Kessinger, T (1975) Vilayatpur 1848 - 1968: Social and Economic Change in a North Indian Village Berkeley: Univesrity of California Press.

Helweg, A (1979) Sikhs in England Oxford, OUP

Marx, K. (1954) The eighteenth Brumaire of Louis Bonaparte London : Lawrence \& Wishart Modood, T et al (1997) Ethnic Minorities in Britain: Diversity and Disadvantage London, PSI

Peach, C. (ed) (1997) The Ethnic Minority Populations of Great Britain: Ethnicity in the 1991 Census Volume Two London: Central Statistics Office

Shaw, A (1988) A Pakistani Community in Britain Oxford: Basil Blackwell

Smith, M and Guarnizo, L. (eds.) (1998) Transnationalism from Below London: Transaction

Visram, R. (1986) Ayahs, Lascars and Princes: Indians in Britain 1700 - 1947 London: Pluto

Werbner P (1989) The Migration Process: Pakistanis in Manchester London, Berg 